\title{
Money Account from Michigan \\ Papyri
}

P. Mich.inv.306 recto $\quad 30 \times 27 \mathrm{~cm}$

Arsinoite (?)

$1^{\text {st }}$. quarter of $2^{\text {nd }} \mathbf{C E}$

\author{
Dr. Magdy A. I. Aly \\ Faculty of Arts, Mansoura University
}

The remains of this "unpublished" roll are light brown in color and of mediocre quality. From the perspective of the recto, it is broken off at the left and possibly the lower edge (though the height of $30 \mathrm{~cm}$ may very well be complete). It is regularly cut at the top, with some breakage, and the upper margin measures about $2 \mathrm{~cm}$. There is a large diagonal lacuna in the middle. One strip of fiber at line 12 in column 1 is slightly misaligned. There are two kolleses, one at ca. $6 \mathrm{~cm}$ from the left edge, the other almost at the right edge, which suggests that a column or more is missing, a fact confirmed by the traces of a missing column at the left side of the verso. The width of the kollema is ca. $20 \mathrm{~cm}$. The recto preserves three columns written with the fibers. Since the first preserved column does not contain a header (e.g. a date, as on verso), one column or more may be missing at the left. The hand is a medium-sized cursive with calligraphic features written in black ink with a thin nib. Entries ending with alpha, sigma, and sometimes with upsilon (especially in the repeated "tókov") have an extended horizontal stroke. There is a diagonal "checking" stroke before the entry at ii.57. The verso text runs against the fibers in rather darker ink with a thicker nib. The hand and format are different from the recto, with blocks of entries organized into rough columns. It contains a heading that is wider than the other blocks of texts and may have been added later. 
The recto contains three columns of an enigmatic money account. The verso ${ }^{1}$, which contains a dated heading, is written in a different hand and is of a different format but contains some overlapping content and thus seems to be related to the account on the other side; it is assumed, therefore, that the recto was written only shortly before, probably in the same $12^{\text {th }}$ year of Hadrian (127/128 CE). The names Lykarion and Noumenios are overwhelming Arsinoite, which points to the likely provenance of the piece.

The account on the recto contains both regularly aligned and indented entries followed by an amount in drachmas; where the entries have been written out in full, the genitive case is used for the regularly aligned entries and the nominative for the indented. This pattern has guided the expansion of abbreviations, but otherwise the significance of the alignment is not clear (the indented entries are not subtotals, for instance). Most entries are for individuals, often but not always identified by a patronymic or attribute. Other entries are for countable items, the most frequent of which is نं several entries for $\mu \alpha v \delta \eta \dot{\lambda} \lambda \alpha$ ("hand towels" or "handkerchiefs") and one for $\beta \alpha \lambda \alpha v \alpha$ pr $\alpha$ ("bath towels," i.10), which suggest the setting of a bathhouse, although the exact logic and purpose of the account remain unclear. Also of

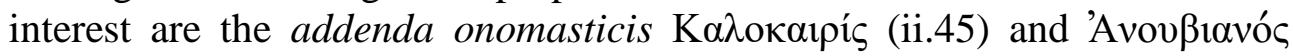
(ii.46). None of the individuals found in the account appear to be attested elsewhere.

Col. I

\begin{tabular}{|c|c|c|}
\hline & 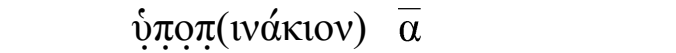 & $\llbracket(\delta \rho.) \eta \rrbracket(\delta \rho.) \eta$ \\
\hline & 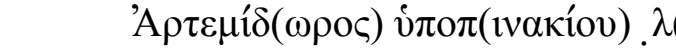 & $(\delta \rho) !$. \\
\hline & 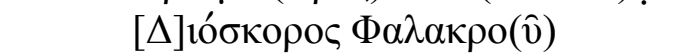 & $(\delta \rho$.$) o \beta$ \\
\hline & 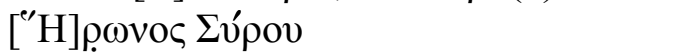 & $(\delta \rho.) \beta$ \\
\hline \multirow[t]{5}{*}{5} & {$[\quad] . \eta \varsigma$} & $(\pi \varepsilon v \tau \omega \beta)$. \\
\hline & 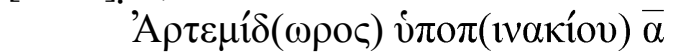 & $(\delta \rho$.$) . (ọß.)$ \\
\hline & $\left.{ }^{\prime} A \mu \mu \omega()\right) \Pi \tau 0 \lambda()$ & $(\delta \rho.) \delta$ \\
\hline & 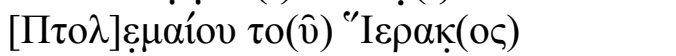 & $(\delta \rho.) \gamma\left(\tau \rho \iota \omega^{\beta} \beta.\right)$ \\
\hline & {[} & $(\delta \rho.) \mu \theta\left(\pi \varepsilon v \tau \omega^{\prime} \beta.\right)$ \\
\hline 10 & 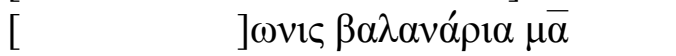 & $(\delta \rho.) \kappa \varsigma$ \\
\hline
\end{tabular}

\footnotetext{
${ }^{1}$ The verso is published in: Magdy A.I Aly, An Account of Money from the University of Michigan, Classical Papers, Vol. XVII. Cairo, December 2020 .
} 
Magdy A. I. Aly

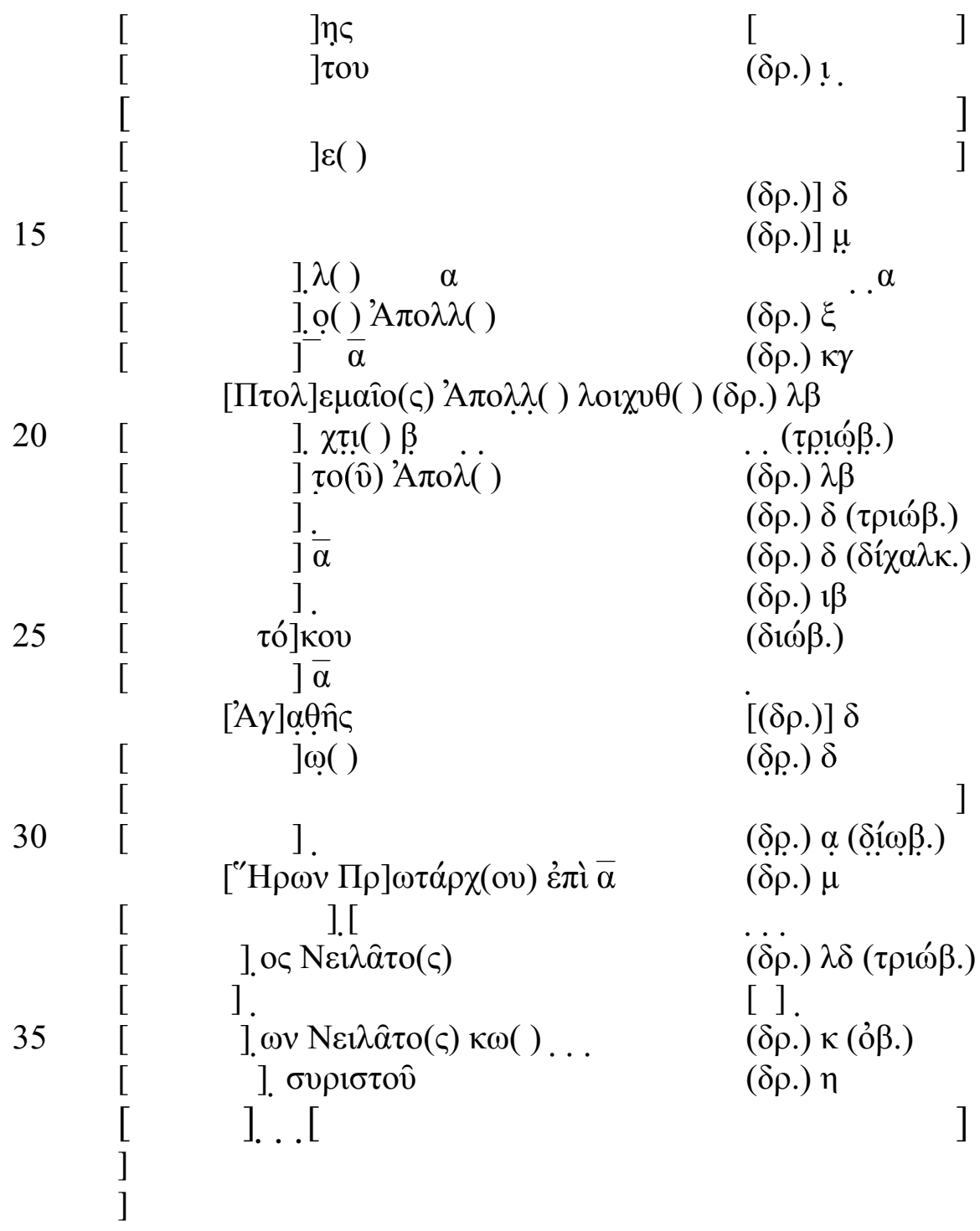

$191 . \lambda \eta \kappa v \theta-?$

Col. II

40

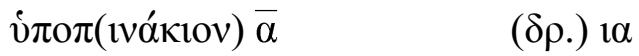

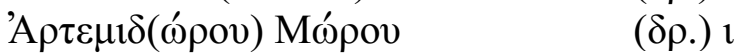

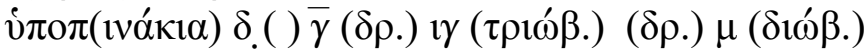

$$
\begin{aligned}
& \text { d } \delta \mu(o i ́ \omega \varsigma) \alpha \quad(\delta \rho .) t \alpha
\end{aligned}
$$

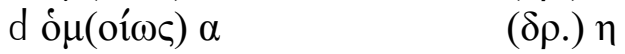




\section{Money Account from Michigan Papyri}

45

50

55

60

65

75

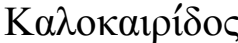

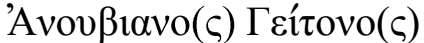

$\Sigma \alpha \rho \alpha \pi \alpha ́ \mu \mu \omega(v){ }^{\complement} \mathrm{E} \rho \mu$ íov

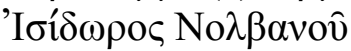

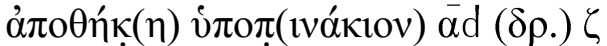

'A $\gamma \alpha \theta \hat{\eta} \varsigma$

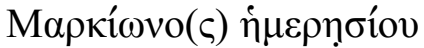

$\dot{\alpha} \rho \pi \varepsilon \delta\left(o_{v \eta} \varsigma\right) \mu v(\hat{\alpha} \varsigma) \alpha$ i $\pi \circ \pi\left(\imath \alpha^{\prime} \kappa \imath \alpha\right) \bar{\beta}(\delta \rho.) \zeta\left(\tau \rho \imath{ }^{\prime} \beta.\right)(\delta \rho.) \imath \delta\left(\delta^{\prime} \chi \alpha \lambda \kappa.\right)$

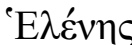

'A $\gamma \alpha \theta \hat{n} \hat{n} \varsigma$

По $\pi \hat{\alpha} \hat{\alpha}$

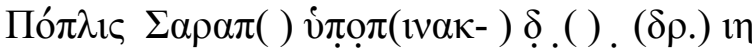
d ó $\mu($ oí $\omega \varsigma) . \alpha($ ) $\quad \alpha$

$\operatorname{Ka\pi } i \tau \omega(v)$

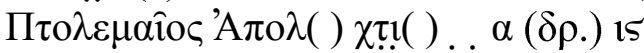
d $\dot{o} \mu($ oí $\omega \varsigma) \alpha$

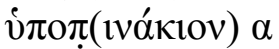

$\dot{\alpha} \rho \pi \varepsilon \delta\left(o_{v} \eta \varsigma\right) \mu v(\hat{\alpha} \varsigma) \alpha$

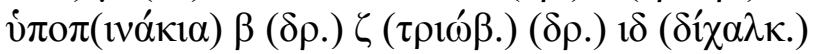

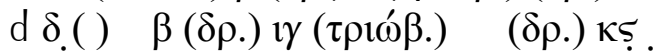
$\mathrm{d} \mu \alpha \nu \delta \hat{\eta} \lambda(\mathrm{lov}) \alpha$

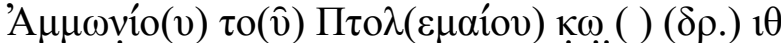

'A $\gamma \alpha \theta \hat{n} \varsigma$

$(\delta \rho.) \delta$

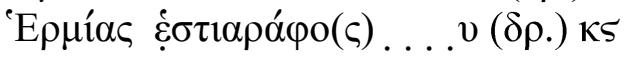

70

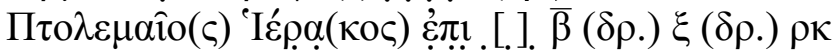

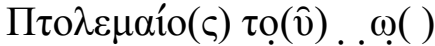

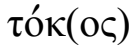

. . $\alpha \sigma \tau \eta \varsigma \Sigma \alpha \rho \alpha \pi() \ldots$

$(\delta \rho.) \rho \kappa$

(jọp.)

$\pi \ldots \ldots$

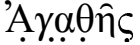

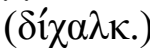

$(\delta \rho.) \delta$

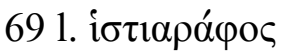

Col. III

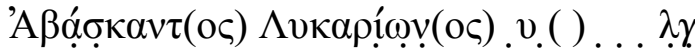 $. \kappa \alpha ! \rho . v \delta() \bar{\alpha}$
$\dot{\alpha} \rho \pi \varepsilon \delta\left(\dot{o}^{\prime} \eta \varsigma\right) \mu \dot{v}(\hat{\alpha} \varsigma) \alpha$
$(\delta \rho.) \delta$ 
Magdy A. I. Aly

80

نं

$\Pi \tau о \lambda \varepsilon \mu \alpha \underline{10} \mathrm{o}(\varsigma)$. .

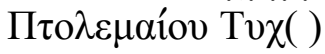

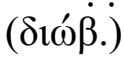

$(\dot{\delta} \rho.) \xi$

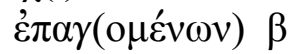

'A $\gamma \alpha \theta \hat{\eta} \varsigma$

$(\delta \rho.) \delta$

85

'А $\beta \alpha \sigma \kappa \alpha ́ v \tau(o v) \Lambda v \kappa \alpha \rho i ́ \omega ̣(o \varsigma)$

$(\delta \rho.) \lambda \varsigma$

نं $\pi$ (เvókıv) $\delta$. ( ) $\alpha$

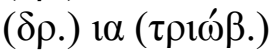

$\mathrm{d} \mu \alpha v \delta\left(\dot{\eta}^{\prime} \lambda_{\mathrm{lov}}\right) \dot{\bar{\alpha}} \kappa$

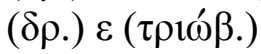

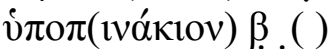

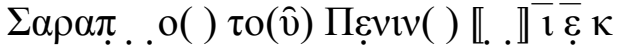

90

d . . $\theta() \bar{\gamma}$

$(\delta \rho$.$) i (\tau \rho ı \omega ́ \beta$.

d $\tau$ óкоv

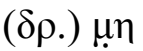

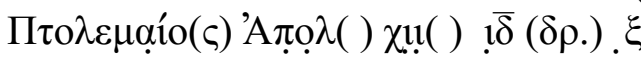

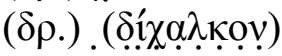

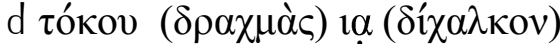

$\Pi \tau \mathrm{o} \lambda \varepsilon \mu \alpha \hat{\imath} \mathrm{o}(\varsigma)$ 'A $\pi \mathrm{o} \lambda(\mathrm{)}) \chi \underline{\mathrm{l}}(\mathrm{l}) \mu \bar{\delta}$.

95

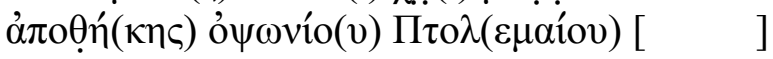
$\mu \alpha v \delta \eta \lambda(i \omega v) \beta(\delta \rho.) \zeta \quad(\delta \rho) .1 \delta$ $\dot{\alpha} \pi \circ \theta \dot{n}(\kappa \eta \varsigma)$

$(\delta \rho.) \varsigma$. vं $\pi$ (เvókıov) $\beta$. ( ) $\alpha$ $\mathrm{d} \mu \alpha\left(v \delta \eta \lambda \lambda^{-}\right) \beta .() .(\delta \rho.) \zeta$

$\alpha \hat{\alpha} \rho \pi \varepsilon \delta(o ́ v \eta \varsigma) \mu v(\hat{\alpha} \varsigma) \alpha$

$\left[\begin{array}{ll}{[} & ] .\end{array}\right] .[\quad] .[$ ].[].[ ].[

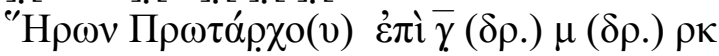

"H

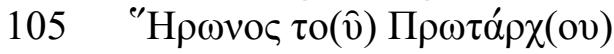
d тóк(ov)

'A $\gamma \alpha \theta \hat{n} \varsigma$ á $\pi \mathrm{o} \theta \dot{\eta}(\kappa \eta) \ldots$.

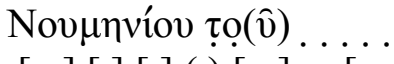

110

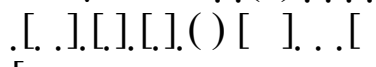

[

$\alpha$.

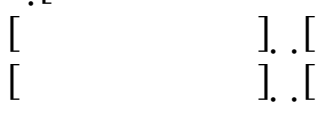

$(\delta \rho.) \beta$

$(\delta \rho). i \beta$

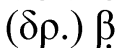

$(\delta \rho.) \delta$

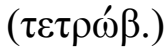

זั0 [ ] . . $(\delta \rho$.$) .$

[
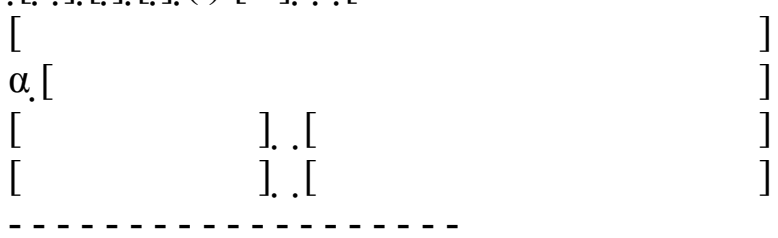

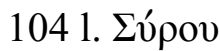




\section{Translation}

Recto

Col. 1:

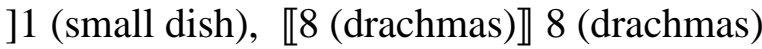

Artemidorus (dish/s?) 1( ) 110 (drachmas)

Dioskoros son of Phalakros 72 (drachmas)

H]yron son of Syros 2 (drachmas)

5- ].es 5 (obols)

Artemidorus (dish/s?) 1 (drachmas),. (obol)

Ammonios son of Ptol( ) 4 (drachmas)

[Ptol] emaios the son of Heracos 3 (drachmas), (3 obols)

] $\quad 49$ (drachmas), (5 obols)

10- Jonis 41 bath-towels, 26 (drachmas)

]es

]tou $\quad 10$ (drachmas)

]

] $4[($ drachmas $)]$

15- ] $40[($ drachmas $)]$

]. 1() ] 1

] o() Apoll() 60 (drachmas)

] a 23 (drachmas)

Ptol]emaios son of Apoll( ) oil-flask 32 (drachmas)

20- ]. chit b (3 obols)

] the son of Apoll( ) 32 (drachmas)

] 4 (drachmas) (3 obols)

] 14 (drachmas) $(2$ chalci)

]. 12 (drachmas)

25- ] ]the interest ( 2 obols)

] 1

Ag]athes $\quad 4[($ drachmas $)]$

\begin{tabular}{rlll} 
& & \multicolumn{3}{c}{4 (drachmas) } \\
$30-\quad$ & {[} & $\ldots \ldots$ & \\
& & $\ldots$ & 1 (drachma) $4,(2$ obols $)$
\end{tabular}

[Heron son of Pr] otarchos in addition to 1, 40 (drachmas)

[ ].[

[ ]. os Neilatos 34 (drachmas), (3 obols) 
Magdy A. I. Aly

35- [ ].on Neilatos ko... 20 (drachmas), . (obols)

$\begin{array}{llc}{[} & \text { ]. syristou } & 8 \text { (drachmas) } \\ {[} & \text {... [ } & \text { ] } \\ \text { ] } & & \end{array}$

Col. 2:

401 small dish, 11 (drachmas)

Artemidorus son Maros 10 drachmas)

4 (small dishes), ( ) 3, 13 (drachmas), (3 obols), 40

(drachmas, (2 obols)

likewise 111 (drachmas)

likewise 18 (drachmas)

45 Calocairidos 8 (drachmas)

Anoubianos son of Geiton 28 (drachmas)

Sarapammon son of Hermios 20 (drachmas)

Isidoros son of Norbanos 40 (drachmas)

The store, 1 (small dish) likewise, 7 (drachmas)

50 Agathes 4 (drachmas)

Markion daily 24 (drachmas)

cord 1 mina, 3 (drachmas), (4 obols)

2 (small dishes), 7 (drachmas), (3 obols), 14 (drachmas),

( 2 chalci)

Helenes, (4 obols)

55 Agathes, 4 (drachmas)

Poplas, (2 obols)

Poplis son of Sarap() (dish/s?) d .( ) ., 18 (drachmas)

likewise a() a [

Kapiton 3 (drachmas) (2 obols)

60 Ptolemaios son of Apol( ) 1, 6 (drachmas)

likewise 1,9 (drachmas) (3 obols)

1(small dish), 10 (drachmas) (3 obols)

cord 1 mina, 4 (drachmas) (3 obols)

2 (small dishes), 7 (drachmas) (3 obols), 14 (drachmas)

( 2 chalci)

65 likewise d( ) 2, 13 (drachmas), (3 obols), 26 (drachmas)

likewise 1 towel [ ]

Ammonios son of Ptolemaios ko ) 19 (drachmas) 


\section{Money Account from Michigan Papyri}

Agathes 4 (drachmas)

Hermias sail-patcher epi.[ ] u 26 (drachmas)

70 Ptolemaios son of Herakos epi.[ ] 2, 60 (drachmas), 120 (drachmas)

Ptolemaios son of .o( ) 120 (drachmas)

the interest $\quad \ldots$

. astes Sarap( ) . . . (drachmas)

.....

75 p..... (2 chalci $)$

Agathes 4 (drachmas)

Col. 3

Abaskanatos son of Lykarion .u ( ) ...lg

. kaiar . ud( ) 1

Cord, 1 mina 4 (drachmas)

$80 \quad 1$ (small dish), . .

Ptolemaios . . .. (2 obols)

Ptolemaios son of Tych( ) 60 (drachmas)

The $2^{\text {nd }}$ intercalary day

Agathes 4 drachmas

85 Abascantos Lykarion 36 (drachmas)

4 (small dishes), ( ) 1, 11 (drachmas), (3 obols)

likewise 1 towels, $\mathrm{k}, 5$ (drachmas), (3 obols)

2 (small dishes), ( ), 10 (drachmas), (3 obols)

Sarap..o( ) son of Penin( ) \. .』15 k

90 likewise ..th( ) 3, 48 (drachmas)

likewise the interest . (drachmas) (2 chalci)

Ptolemaios son of Apol( ) chii( ) 14, 6? (drachmas)

Likewise the interest 11 (drachmas), (2 chalci)

Ptolemaios son of Apol( ) chii( ) 44

95 the pay of the store of Ptolemaios [ ]

2 towels, 7 (drachmas), 4 (drachmas)

the store 6 (drachmas)

2 (small dishes), .( ) . 1 .[

likewise table-cloth b. ( )., 7 (drachmas) [ ]

100 ] cord, 1 mina . (drachmas)

[ ].

[ ]. [ ]. [ ]. [ ]. [ ]. [ 
Magdy A. I. Aly

Heron son of Protarcho(s) epi 3, 40 (drachmas), 120

(drachmas)

Heron son of Syros 2 drachmas

105 Heron son of Protarcho(s), 12 (drachmas)

likewise the interest, 2 (drachmas)

Agathes, 4 (drachmas)

The store of ...., (4 obols)

Noumnious son of ....po [ ]

110

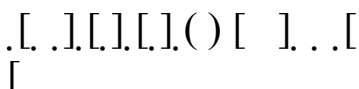

a

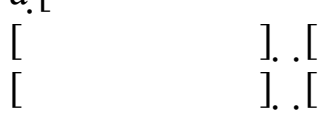

recto

Col. 1

1 i $\pi 0 \pi($ เvókıv). Found repeatedly throughout the account in the form ins) and once expanded to viotv. . ( ) (iii.80). The solution is found on the verso, where in the block of text below and to the right

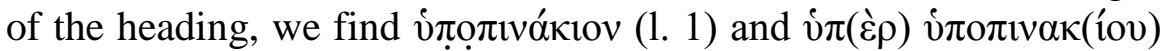

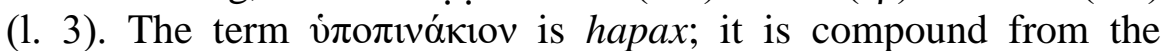
diminutive of $\pi^{i} \mathbf{i} \alpha \xi$. The use of the word is wide (See: $\mathrm{LSJ}^{2}$ ); but since there are some words in recto such as: $\mu \alpha v \delta \eta \dot{\lambda} \lambda 1 \alpha$ ("hand towels" or "handkerchiefs") and one for $\beta \alpha \lambda \alpha v \alpha$ pi $\alpha$ ("bath towels,"), it is possible refers here to "dish/s". The secure amounts for single نं

$3[\Delta]$ ióбкорос $\Phi \alpha \lambda \alpha \kappa \rho о(v) . \quad \Phi \alpha \lambda \alpha ́ \kappa \rho o(v)$ (TM Nam 2463) is also possible.

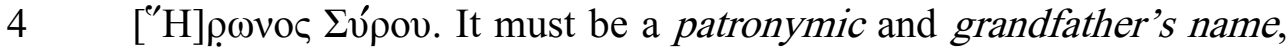
while the name of the person in the missing part. Restored from iii.104.

${ }^{2}$ Henry George Liddell. Robert Scott. A Greek-English Lexicon. revised and augmented throughout by. Sir Henry Stuart Jones. with the assistance of. Roderick McKenzie. Oxford. Clarendon Press with 2005. 


\section{Money Account from Michigan Papyri}

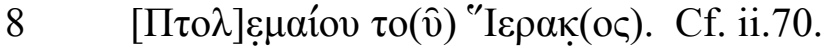

$10 \beta \alpha \lambda \alpha v \alpha \dot{\rho} \rho \alpha \bar{\mu} \alpha$. There are traces above the final alpha of $\beta \alpha \lambda \alpha v \alpha$ pro and the mu whose significance is uncertain.

$19 \lambda \operatorname{or} \chi \theta($ ). Possibly to be understood as a form of $\lambda \eta \kappa v \theta$ iov, "oil flask."

20 Similar entries are found at ii.60, iii.92, and 94, all of which are associated with Ptolemaios, son of Apol( ).

$27\left[{ }^{\prime} \mathrm{A} \gamma\right] \alpha \theta \hat{\eta} \hat{\eta} \varsigma[(\delta \rho).] \delta$. Cf. below, passim. The amount associated with Agathes is always four drachmas.

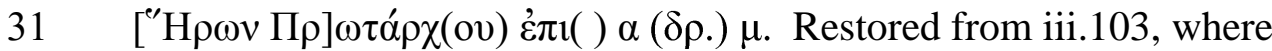
Heron, son of Protarchos, is associated with three installations of 40 drachmas.

Col. 2

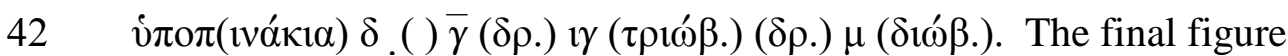
is indeed three times $13 \mathrm{dr}$., $3 \mathrm{ob}$. reckoned on the 7-obol drachma.

$43 \mathrm{~d} \delta \mu(o i ́ \omega \varsigma) \alpha(\delta \rho) .1 \alpha$. The symbol transcribed as $d$ has not been identified. It is similar in shape to the $d$-shaped $1 / 4$ symbol but appears to have the meaning "ditto." If so, the symbol would refer

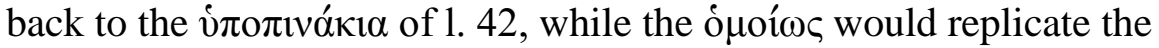
abbreviated word following vंолıvókı 11 and 8 drachmas (the figure in the next line) are in line with the other amounts for

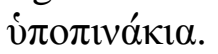

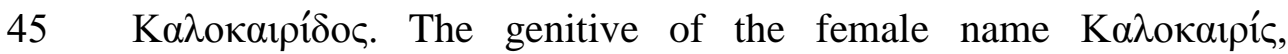

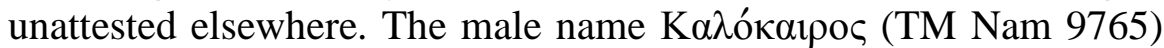

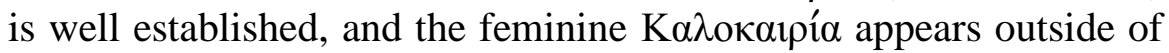
Egypt (LGPN III.B, 225).

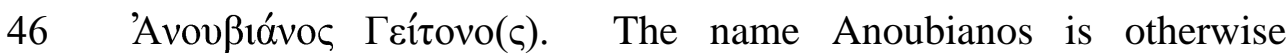
unattested. Geiton is recorded as a personal name in Trismegistos (TM Nam 13544), though the one Greek example is dubious (P.Bour. 15, fr. 5.87; the other is Demotic); the word has been interpreted here as the regular noun. For the same ambiguity, cf. i.3.

48 No $\lambda \beta \alpha v o \hat{v}=$ No $\beta \beta \alpha$ ỗ, Latin Norbanus.

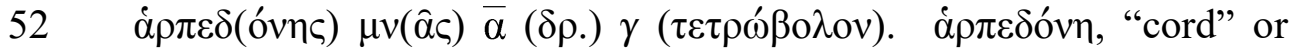
"yarn," has only been attested in three other texts, all Ptolemaic: $S B$ 
22.15276 (middle III BCE); P.Tebt. 3.1 .703 (210 BCE); SB 18.14012 (after $101 \mathrm{BCE}$ ). In the last text, a mina of yarn cost 800 bronze drachmas, which is roughly comparable to the price here on the basis of wheat equivalents: 800 bronze drachmas in the period 130-30 BCE equates to roughly $2 / 3$ of an artaba (for median prices, cf. Maresch 1996: 182), while 3 silver drachmas, 4 obols in the period $30 \mathrm{BCE}$ - to $150 \mathrm{CE}$ equates to a little less than half an artaba of wheat (cf. Drexhage 1991b: 13-15). In line 63, the price for a mina of cord is slightly higher, $4 \mathrm{dr}$., $3 \mathrm{ob}$., while in iii.79 it is $4 \mathrm{dr}$. even.

50 Маркí times in the documents, yet the name Маркıаvóc was probably meant because it is not expected to find the genitive form at the beginning of the line; but rather the scribe was confused and interchanged the omega with alpha.

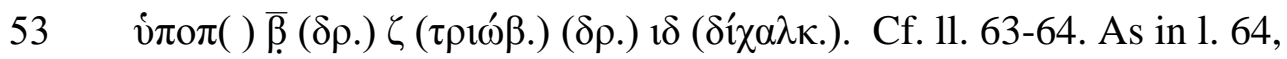
the total falls short of the expected value of $14 \mathrm{dr}$., $6 \mathrm{ob}$.

56 По $\pi \lambda \hat{\alpha} \varsigma$. Presumably related to the Latin name Publius, the named is taken as the Greek hypocoristic По $\pi \lambda \hat{\alpha} \varsigma$ (otherwise unattested). Cf. the next name, spelled Пó $\pi \lambda 1 \varsigma$.

$57 \quad \Sigma \alpha \rho \alpha \pi($ ). This Egyptian theophoric name could be in a compound form such as that in i. $47(\Sigma \alpha \rho \alpha \pi \alpha ́ \mu \mu \omega v)$ the two deities SarapisAmmon, or in a simple form such as $\Sigma \alpha \rho \alpha \pi \hat{\alpha} \varsigma$ or $\Sigma \alpha$ á $\alpha \pi \iota \varsigma$ or $\Sigma \alpha \rho \alpha \pi i ́ \omega v$.

$66 \mu \alpha v \delta \eta^{\prime} \lambda(10 v)$. This is the earliest occurrence of Latin mantele / mantelium, "towel," in Greek papyri.

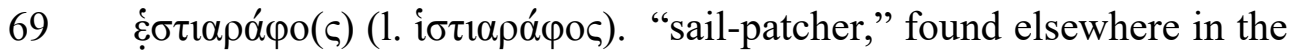
papyri only in P.Cair.Zen. 4.59754.1 (middle III BCE).

Col. 3

$94 \mu \bar{\delta}$. If the dot above mu is meaningful, perhaps instead $\mu \mathrm{o}() \bar{\delta}$. 
Money Account from Michigan Papyri

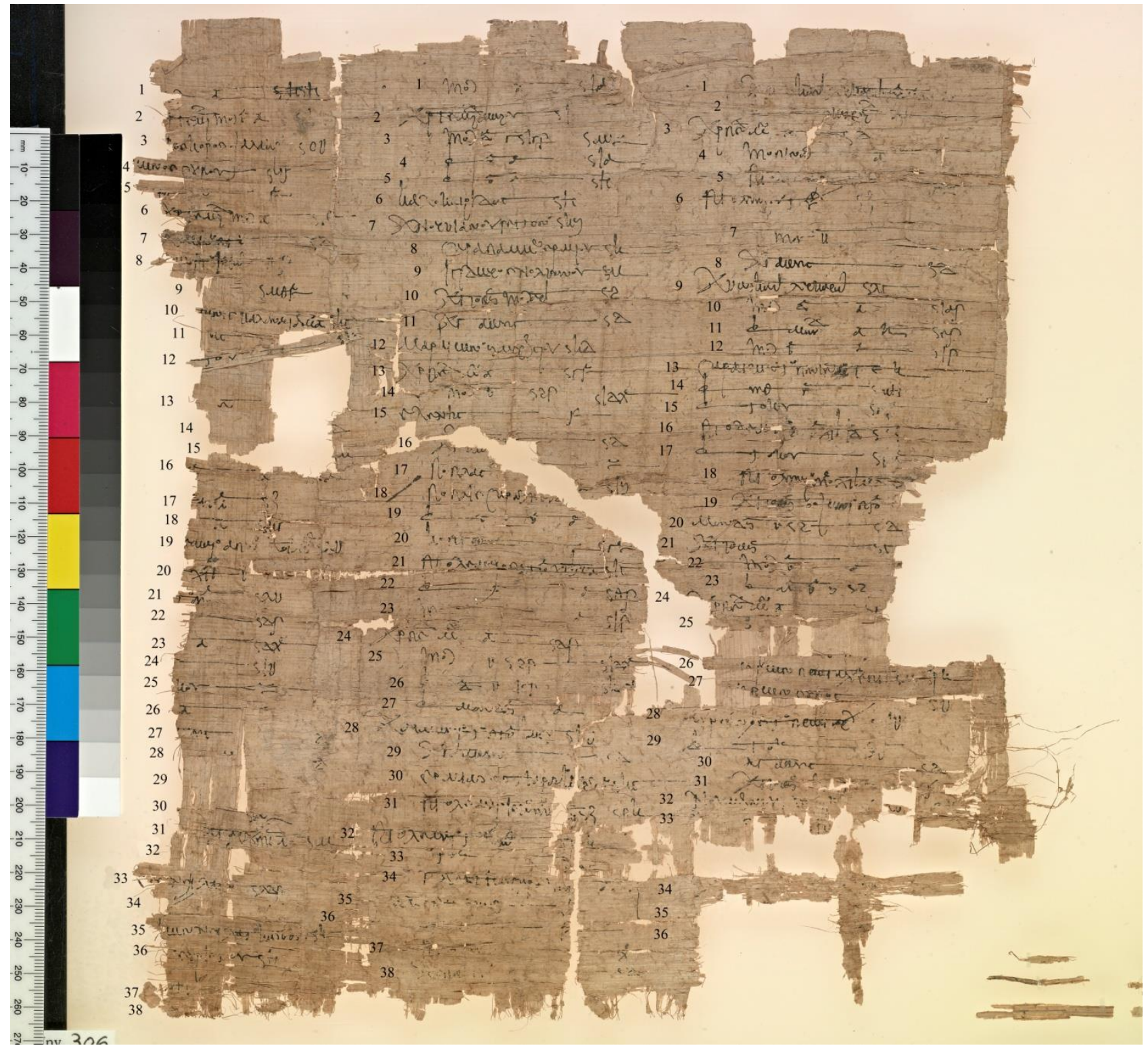

